\title{
El relato fantástico de Amado Nervo en Mundial Magazine. Una interpretación desde la antropología del imaginario
}

Arturo Parrondo ${ }^{1}$

Resumen. Analizamos un conjunto de relatos publicados por Amado Nervo en Mundial Magazine desde la antropología del imaginario y comprobaremos cómo una misma estructura imaginativa configura estos cuentos fantásticos.

Palabras clave: Amado Nervo; cuento fantástico; imagen; imaginario.

[en] The Fantastic Short Story of Amado Nervo in Mundial Magazine. An Interpretation from the Anthropology of the Imaginary

Abstract. We analyze a set of stories published by Amado Nervo in Mundial Magazine from the anthropology of the imaginary and we will verify how the same imaginative structure configures these fantastic stories.

Keywords: Amado Nervo; fantastic story; image; imaginary.

Cómo citar: Parrondo, A. (2020) El relato fantástico de Amado Nervo en Mundial Magazine. Una interpretación desde la antropología del imaginario, en Anales de Literatua Hispanoamericana 49, 155-161.

Dirigida por Rubén Darío desde París, la revista Mundial Magazine ofreció entre los años 1911-1914 una propuesta divulgativa y literaria que se caracteriza por su diversidad temática y cuidada presentación artística. Sus páginas son, desde nuestra perspectiva actual, una excepcional muestra del imaginario fin de siglo debido a la conjunción de palabra e imagen, pues la revista publicó los textos acompañados siempre de ilustraciones, fotografías o motivos ornamentales.

Entre sus páginas literarias, destacan las firmas de reconocidos escritores modernistas que escribieron numerosos cuentos fantásticos a los que Amado Nervo contribuyó con seis relatos ${ }^{2}$. Nuestra interpretación tiene por objetivo subrayar una serie de imágenes simbólicas comunes a todos ellos a partir de la corriente hermenéutica conocida como antropología del imaginario, que tiene en Gilbert Durand su principal valedor. Para ello, procederemos en un primer momento a sintetizar brevemente la teoría del imaginario propuesta por el profesor francés. Después, intentaremos fundamentar la universalidad de la imaginación y cómo una estructura determinada alimenta el imaginario de las obras narrativa. Finalmente, verificaremos cómo los relatos fantásticos de Amado Nervo muestran un conjunto de representaciones que pertenecen al mismo cauce imaginativo.

Esta corriente interpretativa entiende el imaginario como la capacidad de simbolización inherente al hombre, así como el potencial de imágenes que el ser humano puede concebir. Las imágenes simbólicas se entienden como una vía de representación indirecta que se encuentran en un grado superior respecto a las imágenes sensibles o perceptivas. Lejos de las teorías tradicionales, que valoraban la imaginación como una competencia limitada a lo irracional, lo asistemático y lo confuso, esta queda rehabilitada por los trabajos de G. Durand, quien describe esta facultad no solo como una capacidad reproductora, sino creadora y simbólica.

${ }^{2}$ Todos los relatos pertenecen al subgénero fantástico modernista, a excepción del último: "Los congelados", "Cuento de Navidad", "El sexto sentido", "La estrella de los Magos", "Cuentos misteriosos", "Una marsellesa". 
Asimismo, el antropólogo descubre una lógica organizativa entre las imágenes y las cataloga en tres grandes conjuntos denominados diurno, místico y sintético ${ }^{3}$.

Dejando a un lado este último ${ }^{4}$, la estructura diurna es el espacio de las representaciones antitéticas en el que la luminosidad se opone a la nocturnidad tenebrosa; es el régimen del héroe, que concita las imágenes positivas de la luz, la ascensión y la espada, con las que se opone a las representaciones negativas de la noche tenebrosa, la caída y los animales monstruosos. Estas últimas plasman el terror ante el paso del tiempo mientras que las primeras son las armas mediante las cuales el hombre tratará de vencer el devenir y alcanzar la trascendencia. Los arquetipos verbales ${ }^{5}$ que sustentan este cauce del imaginario son los de separar, distinguir y subir; la cohorte de adjetivos relacionados serán lo puro, claro y alto frente a lo mancillado, oscuro y bajo (Durand 2005: 67-196).

Este espacio simbólico de la luz y de las armas es propio del héroe, bien sea en su versión mítica y belicosa, como Hércules, bien sea en la versión medieval caballeresca de Lanzarote o el caballero de la carreta (1181), de Chrétien de Troyes, o bien en la versión degradada y antiheroica del Lazarillo de Tormes (1554), caracterizado por su origen genealógico bajo, alejado de la ascendencia soberana del héroe mítico o medieval. Porque la heroicidad se alimenta de esquemas simbólicos de separación y elevación que funcionan como arquetipos - universales-, encarnándose a través del tiempo en personajes de diferentes ámbitos - mítico, religioso o literario-. Cabe observar que una misma estructura antitética o de oposición caracteriza tanto a héroes como antihéroes y los hacen solidarios de una misma dimensión heroica. Ambos, independientemente del mundo o sociedad a la que pertenezcan, se revelan como excepcionales, no necesariamente por sus cualidades positivas, sino por ser diferentes al resto de la comunidad. En palabras de Alain Verjat, son "heraldos de la diferencia", rasgo que basta para cumplir su función y ser el punto de partida con el que medir si el héroe asciende o desciende, triunfa o fracasa (2000:155-156).

El fin de siglo cuenta con muchos ejemplos de personajes que fracasan en su empresa y que esencialmente se diferencia de sus modelos míticos y caballerescos en que han abandonado el terreno de las gestas para desplazarse al terreno más estético, espiritual y social. Es el héroe que encamina su lucha a la búsqueda de un ideal y se opone de diferentes maneras a las normas impuestas por la sociedad que le circundan. Entre todos los personajes que protagonizan los relatos finiseculares, destacan por su abundancia los del artista y el dandi. Solo en la vertiente hispánica y ciñéndonos a Rubén Darío, fueron protagonistas de muchos de sus cuentos; como el vate mendigo de "La canción del oro" frente a los ricos burgueses, el joven escritor que se opone a la obstinación paterna en "El año que viene siempre es azul" o el rey poeta frente al mecenas Rey Burgués en el cuento homónimo.

El artista en busca de su ideal y el dandi en contra de la sociedad son personajes de raigambre romántica con los que los escritores manifestaban el difícil papel del artista en la sociedad burguesa. Un buen ejemplo de este tipo de heroicidad, alimentada por los esquemas diurnos de separación y elevación, lo ofrece el poeta del relato de Darío, "Primavera apolínea" . El joven debe cumplir con su vocación poética a la que se opone la sociedad materialista que le rodea y que ha elegido para él, frente a la "lira", un destino relacionado con las "transacciones" y "guarismos". El protagonista innominado nos relata cronológicamente su peripecia

${ }^{3}$ En este trabajo emplearemos indistintamente "régimen" y "estructura" para referirnos a un conjunto de imágenes simbólicas que se agrupan por unos rasgos comunes. G. Durand estableció en un inicio dos grandes regímenes, diurno y nocturno, y tres estructuras. La crítica posterior y el mismo autor han dotado de suficiente autonomía a las tres estructuras de manera que es usual el empleo de la siguiente nomenclatura: "diurna" o "heroica", "nocturna" o "mística" y "sintética" o "copulativa". Asimismo, empleamos por igual "imaginario" e "imaginación", siempre teniendo en cuenta que con el segundo término designamos una facultad que no debe confundirse ni con la fantasía, ni con la reproducción de imágenes sensibles, sino con la capacidad creadora y simbólica que tiene el ser humano.

${ }^{4}$ Una tercera estructura, nocturna en su variante sintética, privilegia representaciones en el que se patentiza el tiempo, así se trate del tiempo cíclico mediante la repetición rítmica e infinita o del tiempo histórico orientados por el tiempo lineal del progreso y la biología. Para ello debe actuar sobre la misma sustancia temporal mediante imágenes arquetípicas que en su instancia verbal se caracterizan por la relación en sus distintas variantes como madurar, progresar, volver o enumerar, y cuyas categorías simbólicas correspondientes se concretan en símbolos cíclicos y símbolos de progreso. Los primeros se aprecian en el poder cíclico de la naturaleza, su reiteración mediante las estaciones que se suceden y simbolizan un eterno retorno, o las costumbres sujetas al calendario humano; los segundos, en mitos mesiánicos y filosofías de la historia o del progreso que hacen hincapié en el tiempo lineal y nos recuerdan la finitud de nuestro propio tiempo acosado indefectiblemente por la biología. Son sintéticos porque intentan reconciliar los valores positivos y negativos de la imaginación; el terror que produce su fluidez o ausencia y la esperanza en una victoria sobre él o su conclusión. Además, se caracterizan por convertirse en relatos o mitos en los que alternarán momentos trágicos y triunfantes y combinarán los aspectos negativos y positivos de las imágenes (Durand 2005: 289-354).

${ }^{5}$ El esquema o instancia verbal del arquetipo sería una representación que actúa de puente entre la imagen sensible y la simbólica y se produce cuando la imagen sensible entra en contacto con el sustrato biológico del hombre, donde se hallan los reflejos dominantes posturales, nutricionales y sexuales. El esquema actuaría como matriz arquetipal, verdadero principio ordenador, que clasificaría todo el conjunto de imágenes en tres cauces imaginativos partiendo de los reflejos dominantes del ser humano.

${ }^{6}$ Rubén Darío publicó “Primavera apolínea” en el número 4 de Mundial Magazine. 
vital desde su nacimiento al momento actual, en el que se encuentra narrando su vida en un café parisino. Sus ambiciones son "alas divinas", su pensamiento "como un cóndor solitario adormecido en la grandeza de las peladas cumbres", su camino se orienta siempre hacia "el azul". Este movimiento de emergencia heroica es sentido por el joven como un recorrido de perfeccionamiento puesto que dicha crónica sigue un trayecto ascendente desde la solidaridad y la lucha política en Argentina hasta el descanso amoroso en Europa, donde sustituye su peregrinaje por el amor de una mujer.

Pues bien, la imaginación cuenta con otra manera de afrontar el paso del tiempo; en lugar de representar la ruptura o la confrontación mediante imágenes opuestas, esta puede buscar un refugio que le salvaguarde de los estragos temporales. El espacio simbólico denominado nocturno en su variante mística ${ }^{7}$ alberga dos conjuntos simbólicos: los de la inversión y la intimidad. El primer grupo tratará de invertir el valor negativo de las imágenes diurnas que hemos mencionado: la caída se transforma en descenso, las tinieblas en noche benefactora y el terror animal en engullimiento. Representará, en definitiva, una valoración positiva y tolerable de las imágenes que en el régimen diurno eran amenazantes por simbolizar el tiempo devorador. En el segundo conjunto se hallan los símbolos de la intimidad en los que el hombre encontrará refugio, como el continente y contenido, la morada o el alimento. Los esquemas verbales que representan este arquetipo místico con tendencia a la confusión se relacionan con el descenso, la posesión y la penetración. En correspondencia, lo profundo, lo calmo, lo íntimo y lo oculto serán los arquetipos epítetos que calificarán las imágenes místicas (Durand 2005: 205-275).

Nos parece que este segundo paradigma puede configurar como un arquetipo ${ }^{8}$ muchas obras literarias, ser el germen a partir del cual se configura la imaginación de los relatos.

Así, desde la teoría literaria, pensamos que el segundo tipo de novela concebido por G. Lukács, novela psicológica, en la que la inadecuación se produce entre una interioridad del héroe más amplia que la realidad se origina a partir de un paradigma imaginario místico. La tendencia psicológica será en este caso la de la contemplación, la instalación en la pasividad y la tendencia a evadir el conflicto de manera que se configura una novela en la que priman los estados de ánimo, las reflexiones y el análisis psicológico por encima de la anécdota (2010: 110 y ss.).

Asimismo, la exaltación heroica del caballero, que hemos destacado anteriormente a propósito de la estructura diurna, lleva aparejada una dimensión amorosa que vehicula imágenes pertenecientes al régimen místico, centradas en la valoración positiva de la mujer. Por ejemplo, en Lanzarote, que posteriormente será prototipo de caballeros aventureros y corteses, se da una fidelidad amorosa hacia Ginebra por encima del honor y la muerte, en palabras de García Gual (Blanch 1995: 94). Este añadido de mundanidad, que rompe la armonía y el equilibrio de la cosmovisión clásica, establece una gran diferencia con el héroe mítico. Este tránsito del bastidor épico al novelesco, queda refrendado por el análisis que de la Cartuja de Parma (1840) realizó G. Durand. Fabricio se sumergirá en la intimidad amorosa en un proceso en el que los dos cortejos simbólicos, los de la inversión y la intimidad, permitirán la conversión de los rostros terribles del tiempo en una nocturnidad bienhechora. Así, aparece el amor de Clelia, reverso de los amores fatales que ha experimentado hasta entonces, y la intimidad de los espacios, desde la prisión de la Torre Farnesio, recinto feliz donde experimenta el amor por aquella, hasta las sucesivas capillas e iglesias ${ }^{9}$.

El Romanticismo supone otro hito importante, pues si algo caracteriza a cualquiera de los rostros en los que se encarna el espíritu romántico es en la subjetividad y la introversión, lo que difiere del héroe mítico y caballeresco, siempre en busca de la realización de empresas exteriores. Así, convenimos con A. Blanch cuando resume:

Todo lo cual nos obliga a hablar ahora del "yo romántico" o del "alma romántica", más que de un héroe volcado del todo hacia una gesta. Y en esto consistirá su ejemplaridad primera: invitarnos a entrar en nuestra propia interioridad, para explorarla en sus múltiples laberintos, pero también para aprender a sentir tanto sus anhelos sorprendentes y desmesurados como sus dolorosas e inexcusables contradicciones. (1995: 99-100)

\footnotetext{
${ }^{7}$ Debemos entender "místico" en el sentido de confusión y gusto por la intimidad.

${ }^{8}$ Entendemos arquetipo como una forma primera de representación simbólica, abstracta, universal y heredada (Jung 2010: 5 y 77).

${ }^{9}$ Véase a este respecto el análisis que realiza G. Durand de la conversión del héroe en Le décor mythique de la Chartreuse de Parme. Contribution à l'esthétique du romanesque, Paris: José Corti, 1961. Mismo modelo ha sido puesto a prueba en la lectura de la novela medieval, como en la tesis de $\mathrm{M}^{\mathrm{a}}$ Jesús Salinero Cascante, Para una antropología de lo imaginario en Le Chevalier de la Charrette de Chrétien de Troyes, Universidad de La Rioja, 2010.
} 
Dos tipos denominados por el profesor español como "yo apasionado" y "yo desbordante" tenderán a suscitar imágenes simbólicas propias del régimen nocturno en su vertiente mística. El "apasionado", especialmente cuando se orienta hacia el amor, viene a coincidir con el intimismo que hemos mencionado anteriormente y se encarna, por ejemplo, en el personaje de Werther, mientras que el "desbordante" abre las puertas a lo irracional, a una literatura onírica y fantástica como muestran las composiciones de W. Blake o Samuel T. Coleridge (1995: 106).

Finalmente, debemos precisar que el imaginario de las obras artísticas suelen configurarse a partir de imágenes simbólicas pertenecientes a las tres estructuras. Así puede ocurrir con los relatos cuyo protagonista es el dandi que, además de compartir con el artista el esquema de escisión diurna, vehicula representaciones del régimen místico cuando el personaje se refugia en su propia subjetividad, creando abrigos espaciales en los que rehuir toda actividad heroica. Podría decirse que en estos casos son héroes caracterizados por una merma de su heroicidad; como sucede en la novela À rebours (1884), en la que Des Esseintes, arquetipo de dandi finisecular, se resguarda de la sociedad en una sofisticada mansión proyectada para embeberse en sus reflexiones estéticas, sumergido en el tiempo psicológico cuando fabula, por ejemplo, un viaje imaginario a Londres cuya experiencia le resulta más intensa que la ofrecida por un viaje real.

El último personaje que hemos comentado, nacido de la literatura decadente, no puede entenderse sin aludir a la crisis sufrida por el modelo de pensamiento racional a finales del siglo XIX y que se encuentra en el origen del relato fantástico modernista. Como es sabido, la razón va siendo sustituida por una serie de corrientes irracionalistas, que tienen su base en pensadores anteriores pero que florecen ahora, cuando se reivindica un método de análisis de la realidad alternativo. A todo ello, habría que sumar el deseo del hombre de encontrar una nueva espiritualidad a causa del decepcionante materialismo científico, y que le llevó a sumergirse en corrientes esotéricas como la Sociedad Teosófica o el Rosacrucismo ${ }^{10}$.

Un siglo de progreso incesante tiene como respuesta artística una reivindicación del espíritu, un ahondar en los recovecos del alma humana y una exploración del misterio. En suma, la materia de la que se nutre la narración fantástica. Se trata de la respuesta mística de la imaginación humana ante el monopolio del régimen diurno. A este respecto reproducimos un texto de Dolores Phillipps-López que condensa las motivaciones que se encuentran como causa de lo fantástico y las diferentes vertientes que incluye este tipo de relato:

La racionalización y el progreso científico se hallan en la base del fenómeno de secularización que consistió, como lo formuló Max Weber, precisamente en la "desmiraculización del mundo". Sentido como vacío espiritual, vivido como desgajamiento, este fenómeno se verá signado en la vaga, amplia y renovada religiosidad que caracterizó el fin de siglo. Al acudir al misticismo, al esoterismo y a las supersticiones, al sumar la magia, lo legendario, el milagro, el misterio, el sueño y al describir los estados morbosos o las patologías del alma humana, la ficción fantástica modernista condensa interrogantes y respuestas literarias significativas, busca colmar los vacíos, explorar las nuevas (y replantear las antiguas) fronteras, desbordando límites, instalándose en la muerte misma, complaciéndose en lo excesivo.

Expresando las desorientaciones espirituales, esos confusos sentimientos religiosos que componían saberes doctrinarios múltiples, vinieron a ser "un sustituto de la religión y a la vez una forma de protesta contra el mundo moderno de la ciencia". (2003: 33)

Si bajo el régimen diurno de la imaginación hemos visto brevemente cómo se simbolizaba un tema fundamental de los relatos modernistas como era la confrontación entre el artista y la sociedad, ahora es el momento de examinar cómo los cuentos fantásticos de Amado Nervo se avienen mejor con una imaginación de tipo mística. Comprobaremos como, frente al héroe diurno que buscaba la sublimación mediante esquemas de separación y elevación, la heroicidad mística la buscará animado por esquemas de descenso e intimidad. Frente a los míticos y caballerescos con tendencia a la extroversión, hallaremos los introvertidos que, refractarios a la acción, penetran en el mundo interior "psicología del individuo, exotismo,

${ }^{10}$ Filósofos como Schopenhauer (1788-1860) cuya obra empieza a ser tenida en cuenta a su muerte, sostiene que el mundo se mueve impulsado por fuerzas ciegas e irracionales; Kierkegaard (1813-1860), precedente del existencialismo, propugna un vitalismo angustiado; Nietzche (1844-1900), exalta los impulsos vitales sobre la razón; Henri Bergson (1859-1941), concibe la realidad como algo dinámico que solo puede aprehenderse mediante la intuición o Sigmund Freud (1856-1939), cuya teoría sobre el inconsciente descubre una nueva interpretación de la identidad del individuo. 
ensoñaciones, misterio, más allá". No se trata ya de buscar la transcendencia mediante esquemas de elevación, sino de sumergirse en o confundirse con lo incognoscible.

Notemos de entrada que en el caso del relato modernista hay una propensión a expresar la subjetividad del autor mediante disquisiciones y una estilización verbal que tiende al lirismo en detrimento de la anécdota. Son dos factores que inciden en la devaluación de la representación realística y de las convenciones de la mímesis, de manera que es frecuente que el tiempo y espacio tiendan a lo psicológico, es decir, que difieran del tiempo y espacio objetivos. Esta subjetividad es especialmente acusada en las narraciones que confunden la realidad empírica con la fantasía; la representación que se ciñe más o menos a las convenciones del realismo se fusiona con el relato que no guarda los principios de verosimilitud. Ocurre así en muchos de los cuentos en los que se incorporan personajes mitológicos o literarios, produciéndose una "desrealización de la realidad empírica" al tiempo que se origina una "poetización de la realidad", como ha comprobado Carmen Luna Sellés (2002: 115-116). Dichos personajes ficcionales, que son portadores de unos valores determinados que el escritor quiere subrayar, al incorporarlos al mundo real representado, se produce una fractura por la que la realidad incorpora imágenes adecuadas para vehicular lo misterioso, lo sagrado o lo subjetivo.

En el caso de Amado Nervo, en "El ángel caído" o "Cuento de Navidad", la incorporación de un ser mitológico a la realidad empírica de una familia se hace con total naturalidad cuando un ángel cae de una nube y un niño, compadeciéndose de él, lo lleva a casa para que su madre le cure el ala derecha. El niño, su hermana y el ángel se vuelven inseparables durante su restablecimiento hasta que, finalmente, este debe volver al cielo, produciéndose con este milagro, un segundo hecho insólito, pues han decidido permanecer juntos y el ángel decide llevarse a sus compañeros al cielo.

Amado Nervo elige conscientemente las convenciones narrativas de los cuentos de hadas, comenzando por la fórmula de inicio "Érase...", e incorpora como protagonistas a un ángel desvalido y dos pequeños jóvenes como compañeros, personajes que se encuentran en las antípodas de los héroes extrovertidos y guerreros que deben acometer grandes empresas. Se trata de versiones eufemísticas que se hallan en los relatos tradicionales, como los enanos y Pulgarcito, o bien, como en el caso del ángel - imagen arquetípica de la ascensión diurna- se trata de una representación atenuada a causa de su ala rota. Y es que los personajes aparecen devaluados, son la versión mitigadora de la heroicidad concebida por el régimen místico del imaginario: frente a la fortaleza guerrera del héroe tradicional, encontramos un héroe desvalido; frente al acometimiento de arriesgadas empresas, hallamos el juego de la inocencia infantil. Asimismo, la presencia maravillosa del ángel en la vida de los niños es motivo para lo maravilloso, transgrediendo los límites de la realidad empírica: “¿Cuántos días transcurrieron así? Los niños no hubieran podido contarlos; la sociedad con los ángeles, la familiaridad con el ensueño, tienen el don de elevarnos a planos superiores, donde nos sustraemos a las leyes del tiempo" (MM n $\left.{ }^{\circ} 20,1912: 682\right)$.

Igualmente, en "La estrella de los Reyes Magos", el Rey Gaspar decide detenerse en Jerusalén, donde relata su aventura a un escéptico romano quien, con su visión científica, positiva y lógico-racional, niega la posibilidad de que exista la estrella que ha guiado a los reyes hasta el Niño Jesús. El Rey Mago, después de haber prestado atención a los argumentos del romano, aduce que lo que han seguido no era una estrella en el sentido literal, sino una luz interior:

[...] he acabado por comprender que ésta era una estrella interior... Si — continuó Gaspar con cierta emoción, que dignificaba aún más su noble y anguloso rostro moreno, y ponía en sus grandes ojos de gacela pensativa quién sabe qué fulgores sobrenaturales- sí, era una luz interior, un astro que había nacido en nuestros espíritus. Lo veíamos en una especie de éxtasis, sin acertar á decirnos si nuestro deliquio encendía el lucero, ó el lucero producía nuestro deliquio... Mientras los dromedarios caminaban, proyectando á la luz de la luna sobre el desierto lívido sus cuellos de serpiente, nosotros perseguíamos una visión interna... Quizá íbamos hasta con los ojos cerrados, porque ciertas luces divinas se ven así mejor... Cuando nos arrodillamos ante aquel infante desnudo y tembloroso del establo, la luz de adentro quedó eclipsada por la luz de afuera, por el fulgor que emanaba de los ojos del niño misterioso. ¡El lucero se había hecho carne...! ( $\left.M M \mathrm{n}^{\mathrm{o}} 32,1913: 164\right)$

La imagen simbólica de la luz que encontramos en el relato se halla en el interior, en el espacio confuso de lo incognoscible propio de la imaginación mística. Allí, carece de los atributos propios del régimen diurno como el brillo o el fulgor pues se trata de una luz interior. Recordemos que el régimen diurno, que se halla ligado al reflejo postural y al sentido de la vista, se encuentra aquí devaluado en una "visión interna".

Los personajes del ángel y el Rey Mago abren las puertas de lo fantástico con la recreación de la fantasía infantil y la reivindicación del misterio que llevan aparejados ambos. Se trata de la respuesta con la que el 
escritor fin de siglo, imbuido de una renovada espiritualidad, esgrimía contra la sociedad materialista y científica en la que vivía.

Amado Nervo emplea otros recursos con los que explorar los límites de la realidad empírica. Los avances científicos, que precisamente venían a acabar con la espiritualidad y el misterio, sirvieron de acicate para la imaginación modernista y se incorporaron a los relatos como un medio para penetrar en lo incognoscible. Así, la ciencia cuestiona la finitud de la vida en "Los congelados", posibilita adivinar el futuro mediante una operación quirúrgica en "El sexto sentido" o interpreta el fenómeno conocido como déjà vû en "Cuentos misteriosos".

El joven protagonista de "El sexto sentido" ansía novedades que maten su tedio. Cuando un sabio doctor le ofrece la posibilidad de adquirir el don de la clarividencia mediante una arriesgada intervención quirúrgica en el cerebro, el temerario personaje accede. Tras el éxito de la operación, asistimos a la descripción de las ensoñaciones que durante la aburrida convalecencia tiene el paciente. Se trata de imágenes en las que, debido al nuevo don adquirido, el espacio se vuelve laberíntico y las nociones temporales de pasado y futuro se funden. Visiones interiores calificadas por el protagonista con todo el cortejo de adjetivos vinculados a la confusión propia del régimen místico, como "inefable", "vaguedad indecible", "brumosos panoramas", "inexplicable" o "misterioso" y cuya inefabilidad le obliga a afanarse por encontrar comparaciones que expliquen las percepciones que le otorga su nuevo don.

La imagen medular de estas visiones es la de la futura amada; una joven con los atributos propios de la mujer angelical, que supone la valoración positiva de lo femenino en el régimen nocturno, a diferencia de la mujer fatal del régimen diurno. La percepción de la pureza y levedad angelical de la joven llega con la lentitud propia del descenso místico y asimilada al agua, materia engendradora de vida y vinculada a la maternidad:

Mi asiduidad hizo que mirase en relativamente cercano devenir una vida, que suavemente empezaba en no sé qué recodo del futuro á unirse con la vida mía. Era una mujer, era un rostro... $[\ldots]$

Los primeros días de mi convalecencia los pasé con el alma vuelta toda hacia la visión futura, hacia la rapaza adorable, más adorable á medida que más la contemplaba, en aquella como lontananza gris perla, levemente dorada, en que su silueta rítmica parecía moverse.[...]

Era yo como un Tántalo al revés. Complacíame en ansiar el bien que forzosamente debía pertenecerme; en tener sed del agua mística y milagrosa, que sólo para mí se despeñaba ya de las montañas del Ideal, y corría sonante y cristalina hacia mi boca... $\left(M M \mathrm{n}^{\circ} 27,1913: 230-233\right)$

He aquí todo un conjunto imaginario de la intimidad y la inversión fusionados: un descenso a la vaguedad de la conciencia, una penetración en el interior donde se halla una representación femenina positiva, imagen central de la intimidad amorosa.

El escritor modernista podía sustituir la vulgar realidad en la que habitaba por la recreación de otros tiempos y espacios. Este exotismo, de herencia romántica, consistía en una representación idealizada de lugares remotos y tiempos pretéritos, una evocación estilizada que suponía la vuelta a una especie de unidad original donde buscar refugio.

Cabe mencionar aquí el relato "La Marsellesa" en el que asistimos a las ensoñaciones parisinas de tres muchachos. La parte sustancial del cuento es una rememoración de espacios emblemáticos de París, un sueño imaginativo que es expresión de ocultos deseos y sustitución de la realidad empírica. Este ansiado cosmopolitismo, no es muy diferente de otros exotismos, como la mirada a Jerusalén representada en el cuento de "La estrella de los Reyes Magos" o la recreación del mundo infantil en "Cuento de Navidad", en el que el exotismo entronca con el mito del paraíso perdido. En este sentido, consideramos que la ensoñación idealizada de las ciudades forma parte del exotismo escapista, como apreciaba R. Gullón (1971: 99): "La tendencia del modernismo a lo exótico es el arma del soñador, [...] su importancia no estriba en los contenidos, sino en la actitud; por eso no importa adónde se realice el desplazamiento ilusionado, sino que se realice y se identifique el poeta con el mundo lejano".

En resumen, vemos que en la confusión de la realidad con la fantasía, mediante la incorporación de personajes ficticios; en la exploración de los límites de lo creíble con apoyo de los avances científicos; en el desvelamiento de aquello que se encontraba oculto en la psique humana o en la sustitución de la realidad por un espacio y tiempo exóticos, en todos los casos, se produce un trayecto imaginativo de penetración en lo insondable. Asimismo, hemos comprobado cómo la imaginación mística operaba en diferentes planos y se manifestaba a través de diversas categorías "personaje, tiempo, espacio". 
En el movimiento imaginativo hacia diferentes espacios ocultos, donde reina la confusión, la subjetividad y el misterio, el hombre buscará un refugio que lo salvaguarde del paso del tiempo. Esta interpretación desde la antropología imaginaria viene a coincidir con la que desde el ámbito literario considera que lo fantástico es un sistema de repliegue frente a la realidad y, al mismo tiempo, una compensación y crítica de lo que no se halla en esta (2003: 46).

\section{Referencias bibliográficas}

Blanch, Antonio (1995). El hombre imaginario. Una antropología literaria. Madrid: Universidad Pontificia de Comillas.

Durand, Gilbert (1961). Le décor mythique de la Chartreuse de Parme. Contribution à l'esthétique du romanesque. Paris: José Corti.

Durand, Gilbert (2005). Las estructuras antropológicas del imaginario. Madrid: Fondo de Cultura Económica.

Gullón, Ricardo 1971). Direcciones del modernismo. Madrid: Gredos.

Jung, Carl Gustav (2010). Los arquetipos y lo inconsciente colectivo. Obra completa, volumen 9/1. Madrid: Trotta.

Lukács, György (2010). Teoría de la novela: un ensayo histórico-filosófico sobre las formas de la gran literatura épica. Buenos Aires: Godot.

Luna Sellés, Carmen (2002). La exploración de lo irracional en los escritores modernistas hispanoamericanos. Literatura onírica y poetización de la realidad. Santiago de Compostela: Universidad de Santiago de Compostela.

Nervo, Amado (1911), "Los congelados", Mundial Magazine, $\mathrm{n}^{\circ} 6$ (octubre, 1911), pp. 559-561.

Nervo, Amado (1912), "Cuento de Navidad", Mundial Magazine, $\mathrm{n}^{\circ} 20$ (diciembre, 1912), pp. 680-683.

Nervo, Amado (1913), "El sexto sentido", Mundial Magazine, no 27 (julio, 1913), pp. 226-239.

Nervo, Amado (1913), "La estrella de los Magos", Mundial Magazine, no 32 (diciembre, 1913), pp. 163-166.

Nervo, Amado (1914), "Cuentos misteriosos", Mundial Magazine, no 34 (febrero, 1914), pp. 392-393.

Nervo, Amado (1914), "Una marsellesa”, Mundial Magazine, no 40 (agosto, 1914), pp. 338-340.

Phillipps-López, Dolores (2003). Cuentos fantásticos modernistas de Hispanoamérica. Madrid: Cátedra.

Salinero Cascante, María Jesús (2010). Para una antropología de lo imaginario en Le Chevalier de la Charrette de Chrétien de Troyes. Universidad de La Rioja. Tesis doctoral.

Verjat Massmann, Alain (2000), "Mitemas del héroe", Thélème: Revista complutense de estudios franceses, $\mathrm{n}^{\circ} 15$ (2000), pp. 153-164. 